\title{
JAMINAN PERLINDUNGAN HUKUM TERHADAP KESEHATAN DAN KESELAMATAN KERJA KEPADA TENAGA KERJA KONSTRUKSI
}

\section{“Guarantee Of Legal Protection For Occupational Health And Safety For Construction Workers"}

\author{
Condro S. Riyadi, Mutia CH. Thalib \\ Fakultas Hukum Universitas Negeri Gorontalo, Jl. Jend. Soedirman No. 6 Kota Gorontalo. \\ Korespondensi: Email: condroriyadi00@gmail.com
}

\begin{abstract}
ABSTRAK
Tujuan Penelitian adalah untuk Mengetahui dan Menganalisis tentang Perlindungan Hukum Jaminan Kesehatan dan Keselamatan Kerja (K3) Terhadap Tenaga Kerja Konstruksi di Provinsi Gorontalo. Jenis Penelitian yang digunakan oleh peneliti dalam menyusun Penelitian ini adalah jenis Penelitian normatifempiris, Adapun pendekatan yang digunakan oleh peneliti dalam menyusun penelitian ini adalah, antara lain: Pendekatan Perundang-Undangan (Statue Approach); Pendekatan kasus (case approach). Hasil Penelitian ini menujukkan: Pertama, bahwa Perlindungan Hukum Jaminan Kesehatan dan Keselamatan Kerja (K3) Terhadap Tenaga Kerja Konstruksi di Provinsi Gorontalo. sampai dengan saat ini berdasarkan temuan penelitian yang didapatkan dari narasumber telah berjalan dengan baik, sebab hampir sebagian besar perusahaan konstruksi telah memenuhi kewajibannya untuk memberikan jaminan asuransi kepada para pekerjanya. Kemudian terkait dengan implementasi K3 dalam aspek pemenuhan standar keselamatan kerja melalui alat pelindung diri (APD) semuanya disediakan oleh pihak perusahaan kepada para pekerjanya. Dengan demikian dapat ditarik kesimpulan bahwa sejauh ini jaminan perlindungan hukum terkait dengan kesehatan dan keselamatan kerja (K3) berjalan dengan baik di provinsi Gorontalo. Kedua, bahwa Faktor Penghambat Perlindungan Hukum Jaminan Kesehatan dan Keselamatan Kerja (K3) Terhadap Tenaga Kerja Konstruksi di Provinsi Gorontalo. Adapun hasil indentfikasi mengenai hambatan yang dimaksud, yakni: Lemahnya Pengawasan Ketenagkerjaan; Faktor Sumber Daya Manusia; Faktor Anggaran; Faktor Kesedaran Pekerja; dan Kurangya Kesadaran Pimpinan Perusahaan untuk mendaftarakan Pekerja ke dalam program Jaminan Sosial Tenaga Kerja (Jamsostek).
\end{abstract}

Kata Kunci: Perlindungan Hukum; Kesehatan Dan Keselamatan Kerja; Tenaga Kerja Konstruksi.

\section{ABSTRACT}

Research objectives are to know and analyze the legal protection of occupational health and safety (K3) insurance against construction workers in Gorontalo province. This type of research used by researchers in compiling this research is a type of normative-empirical research. The approaches used by researchers in compiling this research are, among others: The Legislative Approach (Statue Approach); The case approach. The results of this study indicate: First, that the Legal Protection of Health and Safety Insurance (K3) Against Construction Workers in Gorontalo Province. up to now, based on the research findings obtained from informants, it has been going well, because most construction companies have fulfilled their obligations to provide insurance guarantees to their workers. Then related to the implementation of K3 in the aspect of meeting work safety standards through personal protective equipment (PPE), everything is provided by the company to its workers. Thus it can be concluded that so far legal protection guarantees related to occupational health and safety (K3) are running well in Gorontalo province. Second, that the Inhibiting 
Factors for Legal Protection of Occupational Health and Safety Insurance (K3) Against Construction Workers in Gorontalo Province. The results of identification of the obstacles in question, namely: Weak Labor Inspection; Human Resources Factor; Budget factor; Facility and Infrastructure Factor; and Lack of Awareness of Company Leaders to register Workers in the Workers' Social Security (Jamsostek) program. Keywords : Legal Protection; Occupational Health and Safety; Contruction Workers.

\section{PENDAHULUAN}

\section{Latar Belakang}

Perwujudan negara hukum Indonesia tercermin dari peraturan perundangundangan yang dibuat untuk memberi pedoman bagi rakyat dalam menjalankan aktivitasnya sebagai warga negara, (Achir, 2020) termasuk dalam aspek pekerjaan. Perburuhan atau ketenagakerjaan di Indonesia diatur berdasarkan UndangUndang Nomor 13 Tahun 2003, tepatnya dalam Bab 1 Pasal 1, ditegaskan bahwa ketenagakerjaan dinyatakan adalah semua hal yang berkaitan dengan pekerjaan pada saat itu sebelum, selama dan setelah bekerja. Dalam hal ini, sesuai dengan pasal 1 angka 2 Undang-Undang Nomor 13 tahun 2003 tentang Ketenagakerjaan yang dimaksud dengan Tenaga Kerja adalah setiap orang yang mampu melakukan pekerjaan untuk menghasilkan barang dan/atau jasa untuk kebaikan memenuhi kebutuhan mereka sendiri dan untuk masyarakat. ${ }^{1}$

Posisi pengusaha dan pekerja dalam hukum ketenagakerjaan sama dan sederajat, akan tetapi secara sosiologis pada suatu kondisi tertentu posisi antara karyawan (pekerja) dan pengusaha tidak setara dan seimbang, karena karyawan (pekerja) sering berada dalam posisi lemah. ${ }^{2}$ Dunia tenaga

\footnotetext{
1 Suhartoyo. 2019. Perlindungan Hukum Bagi Buruh Dalam Sistem Hukum Ketenagakerjaan Nasional. Adminitrative Law \& Governance Journal. 2 (2): 326-327 ${ }^{2}$ Sudarjadi, Kompilasi Hukum Kenegakerjaan Jamsostek, (Yogyakarta: Pustaka Yustisia, 2010), hal.15
}

kerja harus menjadi perhatian bersama, dimulai dengan bimbingan, pengarahan, dan perlindungan tenaga kerja.

Bekerja dalam industri manufaktur terdapat risiko bahaya karena kurangnya Keselamatan dan Kesehatan Kerja (K3) dapat ditemukan pada peralatan kerja, bahan kimia berbahaya seperti asam dan soda kaustik dan mesin produksi. Jenis kecelakaan pekerjaan yang dapat terjadi di sektor produksi yakni, terjepit, terlindas, terpotong, jatuh, tindakan yang salah, tertabrak, kontak dengan zat berbahaya, jatuh, berguling, jatuh dari atas, terpukul keras, dan pingsan. Sebuah proses produksi, peralatan dan mesin di tempat kerja jika mereka tidak mendapatkan Perhatian khusus akan mengarah pada potensi kecelakaan di tempat kerja. ${ }^{3}$

Pekerjaan di bidang konstruksi bangunan, keamanan, keselamatan, dan kesehatan kerja (K3) merupakan salah satu faktor yang sangat penting untuk diperhatikan karena apabila sesorang yang mengalami sakit atau kecelakaan dalam bekerja akan berdampak pada diri sendiri, keluarga, lingkungan dan perusahaan tempat bekerja. Keamanan, Keselamatan, dan Kesehatan kerja merupakan salah satu aspek perlindungan ketenaga kerjaan yang di atur dalam Undang-Undang Nomor 13 Tahun 2003 Tentang Ketenagakerjaan. Penerapan

3 Fenny Nathalie Khoe, 2013. Hak Pekerja Yang Sudah Bekerja Namun Belum Menendatangani Perjanjian Atas Upah Ditinjau Berdsarkan Undang Undang Nomor 13 Tahun 2003 Tentang Ketenagakerjaan, Jurnal ilmiah Mahasiswa Universitas Surabaya. 2 (1): 3 
teknologi pengendalian keselamatan dan keamanan kerja, dapat menjadi harapan bagi tenaga kerja agar mencapai ketahanan fisik, daya kerja, dan tingkat kesehatan yang tinggi. Oleh karena itu, unsur yang ada didalam keamanan, kesehatan, dan keselamatan tidak terpaku pada faktor fisik, tetapi juga mental, emosional dan psikologi, serta teknologi yang ada. Masalah pekerjaan itu sering terjadi dengan cara tertentu, secara umum ketidakpuasan ini biasanya bervariasi pada masalah; pengupahan; jaminan sosial; perilaku penugasan yang terkadang tidak sesuai dengan kepribadian; Tenaga kerja dan kapasitas kerja yang kurang terlihat dengan pekerjaan yang harus dilakukan; Masalah pribadi. $^{4}$

Berdasarkan data yang dirilis oleh Kementerian Pekerjaan Umum, bahwa jumlah pekerja yang bekerja di sektor jasa Konstruksi di Indonesia sampai dengan saat ini adalah 8,14 juta orang tenaga kerja, dengan presentasi berdasarkan tingkat pendidikan sebanyak 5, 98 juta orang yang pendidikanya di bawah sekolah menengah atas (SMA), dan pendidikan di atas sekolah menengah atas sebanyak 2,15 juta orang. Daro total 8,14 juta tenaga kerja tersebut, yang tersertifikasi berdasarkan rilis dari Kementerian PU sampai dengan tahun 2019 sebanyak 525.857 untuk tenaga terampil (analis/teknisi dan operator) dan sertifikat tenaga ahli sebanyak 241.322. Sedangkan, dilihat dari jumlah tenaga kerjanya yang sudah tersertifikasi sebanyak 485.534 orang dengan komposisi tenaga terampil sebanyak 333.706 orang dan tenaga ahli sebanyak 151.828 orang. $^{5}$

Setiap pekerjaan selalu mengandung potensi resiko bahaya dalam bentuk kecelakaan kerja. Besarnya potensi

\footnotetext{
4 R. Joni Bambang, Hukum Kenegakerjaan, (Bandung: Pustaka Setia, 2013), Hal. 289

5 http://binakonstruksi.pu.go.id/jdownloads/Buletin/ BULETIN EDISI 6 2018.pdf diakses pada 25 Februari 2020 pada pukul 09:00 Wita.

6 http://m.harnas.co/2017/03/01/kemenakerkematian-akibat-kecelakaan-kerjatinggi.html. Diakses pada 25 Januari 2020 pada pukul 13:30 Wita. Lihat
}

kecelakaan dan penyakit kerja tersebut tergantung dari jenis produksi, teknologi yang dipakai, bahan yang digunakan, tata ruang dan lingkungan bangungan serta kualitas manajemen dan tenaga tenaga pelaksana. Angka kecelakaan kerja konstruksi di Indonesia masih termasuk buruk. Tahun 2015 tercatat 2.375 orang Meninggal dalam Kecelakaan Kerja Menurut Juan Somavia, Dirjen ILO, industri konstruksi termasuk paling rentan kecelakaan. Selain itu juga Perlindungan hukum bagi karyawan masih dianggap sebagai beban biaya, sehingga beberapa perusahaan menggunakan alat pelindung diri yang tidak memenuhi standar. Ini diperburuk oleh kehadiran alat perlindungan pribadi palsu. Menurut data dari BPJS Ketenagakerjaan, bahwa terdapat 157.313 kasus di 17.069 perusahaan dari 359.734 perusahaan terdaftar dengan korban tewas tidak kurang dari 2.382 orang hingga pada November 2018. Angka kecelakaan di tempat kerja dan sakit karena bekerja di Indonesia masih dianggap cukup tinggi. Salah satu penyebabnya adalah rendahnya perlindungan hukum terhadap tenaga kerja. ${ }^{6}$

Secara spesifik jika ditelisik dalam lingkup wilayah daerah, maka sebagai suatu bentuk analisa di Provinsi Gorontalo, jumlah angkatan kerja yang tercatat sampai dengan agustus 2019 tercatatat berjumlah 585.896 orang, untuk Kota Gorontalo sendiri jumlah tenaga kerja yang bekerja di sektor jasa Konstruksi yakni sejumlah 5.794 orang tenaga kerja, pekerja tersebut tersebar di 1.404 perusahaan jasa konstruski di Kota Gorontalo, Industri kima dan bahan bangunan menyumbang pekerja terbanyak, yakni sebanyak 1.770 orang. $^{7}$

juga data terkait dengan jumlah tenaga kerja yang mengalami kecelakaan di https://ekonomi.bisnis.com/read/20190115/12/878 723/sepanjang-2018-kemnaker-catat-terjadi157.313-kecelakaan-kerja.

7 BPS, Direktori Perusahaan Konstruksi Provinsi Gorontalo 2019, (Gorontalo, BPS, 2019), hal. 25 
Sementara itu, berdasarkan Data Badan Penyelenggara Jaminan Sosial (BPJS) Ketenagakerjaan Gorontalo mengungkap, dalam rentang waktu empat tahun terakhir (2016-2019), sebanyak 331 kecelakaan kerja yang terjadi di Provinsi Gorontalo. Sedangkan berdasarkan observasi, bahwa dari data yang diperoleh, jumlah proyek selama tahun 2017 sekitar 357 proyek dengan tenaga kerja harian lepas berjumlah 51.211. Sayangnya, bentuk tanggungjawab dan perlindungan pekerja pada kegiatan proyek APBN, APBD dan Swasta ini masih belum berjalan dengan semestinya. $^{8}$

Prinsipnya berdasarkan hal di atas maka keberadaan jumlah pekerja jasa konstruksi yang cukup banyak yang tersebar di wilayah Provinsi Gorontalo khsusnya di Kota Gorontalo selalu beririsan dengan hak dan kewajiban yang diterima oleh pekerja-pekerja di bidang jasa konstruksi terutama terkait dengan perlindungan hukum terhadap tenaga kerja pada proyek pembangunan konstruksi. Berdasarkan uraian tersebut, maka perlu adanya kajian yang lebih komprehensif terkait dengan jaminan perlindungan hukum terhadap Kesehatan dan Keselamatan Kerja (K3) kepada tenaga kerja konstruksi di wilayah Provinsi Gorontalo.

\section{Rumusan Masalah}

Adapaun rumusan masalahnya adalah;

1. Bagamana perlindungan hukum jaminan Kesehatan dan Keselamatan Kerja (K3) terhadap tenaga kerja konstruksi di Provinsi Gorontalo?

2. Apa faktor penghambat perlindunganhukum jaminan Kesehatan dan Keselamatan Kerja (K3)

8 https://hargo.co.id/berita/pekerja-jasa-konstruksiwajib-dilindungi.html Diakses pada 25 Januari 2020 pada pukul 13:30 Wita.

${ }^{9}$ Ahmad Huanaeni Zulkarnain dan Tanti Kirana Utami. 2016. Perlindungan Hukum Terhadap Pekerja Dalam Pelaksanaan Hubungan Industrial. Jurnal Padjajaran Ilmu Hukum, 3 (2): 407-408

10 Ujang Charda S. 2010. Perlindungan Hukum Ketenagakerjaan Terhadap Tenaga Kerja Anak Yang terhadap tenaga kerja konstruksi di Provinsi Gorontalo?

\section{Metode Penelitian}

Jenis Penelitian yang digunakan oleh peneliti dalam menyusun Penelitian ini adalah jenis Penelitian normatif-empiris, ditunjang dengan data lapangan. Adapun pendekatan yang digunakan dalam penelitian ini adalah, antara lain; Pendekatan PerundangUndangan (Statue Approach); dan Pendekatan Kasus (case approach). Analisis yang digunakan dalam penelitian ini adalah analisis data deskriptif dengan menggunakan pendekatan kualitatif terhadap data primer dan data sekunder.

\section{PEMBAHASAN}

\section{Perlindungan Hukum Jaminan Kesehatan dan Keselamatan Kerja (K3) Terhadap Tenaga Kerja Konstruksi di Provinsi Gorontalo}

Indonesia menganut prinsip negara kesejahteraan (walfare state), ${ }^{9}$ olehnya Berdasarkan Undang-Undang Dasar Negara Republik Indonesia Tahun 1945, Pasal 27 ayat (2) yang menyatakan bahwa tiap-tiap warga negara berhak atas pekerjaan dan penghidupan yang layak bagi kemanusiaan, ${ }^{10}$ begitu juga dengan Undang-Undang Nomor 14 Tahun 1969 BAB IV Tentang Pembinaan Perlindungan Kerja tertulis bahwa tenaga kerja berhak mendapatkan perlindungan atas keselamatan, kesehatan, kesusilaan, pemeliharaan moril kerja serta perlakuan yang sesuai dengan martabat manusia dan moral agama. ${ }^{11}$ Hak ini merupakan suatu hal

Bekerja Di Luar Hubungan Kerja Pada Bentuk Pekerjaan Terburuk. Jurnal Ilmu Hukum (Syiar Hukum), 12 (2): 117

11 Unggul Priyadi. et. al. 2013. Pendampingan Hukum Hak Pekerja (Usia Produktif) Berdasarkan Hukum Ketanagakerjaan. Jurnal Inovasi dan Kewirausahaa. 2 (2):101 
yang pokok sebab hak setiap orang yang tidak bisa ditunda atau bahkan dihilangkan. ${ }^{12}$

Perlindungan hukum mempunyai makna sebagai perlindungan dengan menggunakan sarana hukum atau perlindungan yang diberikan oleh hukum, ditunjukan terhadap kepentingankepentingan tertentu, yaitu dengan cara menjadikan kepentingan yang perlu dilindungi tersebut ke dalam sebuah hak hukum. Dalam hukum "hak" disebut juga hukum subyektif. Hukum subyektif merupakan segi aktif dari pada hubungan hukum yang diberikan oleh hukum obyektif, dalam hal hukum subyektif adalah normanorma, kaidah. ${ }^{13}$

Ketentuan Pasal 5 Undang-Undang Republik Indonesia Nomor 13 Tahun 2003 Tentang Ketenagakerjaan secara yuridis memberikan perlindungan bahwa setiap tenaga kerja berhak mempunyai kesempatan yang sama untuk memperoleh pekerjaan dan penghidupan yang layak tanpa menbedakan jenis kelamin, suku, ras, agama, dan aliran politik sesuai dengan minat dan kemampuan tenaga kerja yang bersangkutan, termasuk perlakuan yang sama terhadap para penyandang cacat. Sedangkan Pasal 6 Undang-Undang Republik Indonesia Nomor 13 Tahun 2003 Tentang Ketenagakerjaan bahwa mewajibkan pengusaha untuk memberikan perlakukan yang sama kepada pekerja/buruh tanpa membedakan jenis kelamin, suku, ras, agama dan aliran politik.

Perlindungan tenaga kerja meliputi aspek-aspek yang cukup luas, yaitu perlindungan dari segi fisik yang mencakup perlindungan keselamatan dari kecelakaan kerja dan kesehatannya serta adanya pemeliharaan moril kerja dan perlakuan yang sesuai dengan martabat manusia dan moral agama, sebagaimana telah ditegaskan pada Pasal 86 Undang-Undang Ketenagakerjaan.

12 Akbar Faizal. Politik Hukum Perlindungan Hakim. Jurnal Cita Hukum. Volume 4 Nomor 1, Juni 2016. Hlm. 13
Setiap tenaga kerja mempunyai hak untuk memperoleh perlindungan atas:

1. Keselamatan dan kesehatan kerja;

2. Moral dan kesusilaan;

3. Perlakuan yang sesuai dengan harkat dan martabat serta nilai-nilai agama.

Perlindungan tersebut dimaksudkan agar tenaga kerja dapat secara aman melakukan pekerjaannya sehari-hari sehingga dapat meningkatkan produksi dan produktivitas pekerjaannya. Tenaga kerja harus memperoleh perlindungan dari berbagai peristiwa disekitarnya dan pada dirinya yang dapat menimpa dan menggangu dalam pelaksanaan pekerjaanya. Dalam bidang konstruksi, ada beberapa peralatan yang digunakan untuk melindungi seseorang dari kecelakaan ataupun bahaya yang mungkin bisa terjadi dalam proyek konstruksi. Peralatan ini wajib digunakan oleh seseorang yang bekerja dalam suatu lingkungan konstruksi.

Berdasarkan Pasal 166 UndangUndang Nomor 13 Tahun 2003 Tentang Ketenagakerjaan, dalam hal hubungan kerja berakhir karena pekerja/buruh meninggal dunia, kepada ahli warisnya diberikan sejumlah uang yang besar perhitungannya sama dengan perhitungan 2 (dua) kali uang pesangon sesuai ketentuan Pasal 156 Ayat (2) Undang-Undang Ketenagakerjaan, 1 (satu) kali uang penghargaan masa kerja sesuai ketentuan Pasal 156 Ayat (3) Undang-Undang Ketenagakerjaan, yakni sebesar tiga bulan upah dan uang penggantian hak yang seharusnya diterima. Uang penggantian hak tersebut meliputi: Cuti tahunan yang belum diambil dan belum gugur, biaya atau ongkos pulang untuk pekerja/buruh dan keluarganya ketempat dimana pekerja/buruh diterima bekerja, penggantian perumahan serta pengobatan dan perawatan ditetapkan 15\%

13 Heru Suyanto dan Andriyanto Adhi Nugroho. 2016. Perlindungan Hukum Terhadap Hak-Hak Pekerja Outsourcing Berdasarkan Asas Keadilan. Jurnal Yuridis. 3 (2): 4 
dari uang pesangon dan/atau uang penghargaan masa kerja bagi yang memenuhi syarat dan hal-hal lain yang ditetapkan dalam perjanjian kerja, peraturan perusahaan dan perjanjian kerja bersama.

\begin{tabular}{ccc} 
& Undang-Undang & \multicolumn{2}{c}{ Ketenagakerjaan } \\
telah diatur beberapa pasal untuk
\end{tabular}
memberikan perlindungan kepada para pekerja. Perlindungan ini sebagai wujud pengakuan terhadap hak-hak para pekerja sebagai manusia yang harus diperlakukan secara manusiawi dengan mempertimbangkan

keterbatasan kemampuan fisiknya. ${ }^{14}$ Dalam UndangUndang No.13 Tahun 2003, lingkup perlindungan terhadap pekerja antara lain meliputi:

a. Perlindungan atas hak-hak dasar pekerja atau buruh untuk berunding dengan pengusaha;

b. Perlindungan keselamatan dan kesehatan kerja;

c. Perlindungan khusus bagi pekerja atau buruh perempuan;

d. Perlindungan tentang upah, kesejahteraan, dan jaminan sosial tenaga kerja. ${ }^{15}$

\section{Mencermati Undang-Undang}

Ketenagakerjaan sebenarnya telah mengatur persoalan waktu kerja, Perlindungan, Pengupahan, dan Kesejahteraan. Maka peneliti merasa perlu untuk melakukan validasi terhadap mekanisme perlindungan hukum yang diatur di dalam UU Ketenagakerjaan tersebut. Proses ini dilakukan selain untuk mendapatkan jawaban tentang permasalahan yang diangkat, juga dimaksudkan untuk mengukur sejauh mana proses perlindungan hukum terhadap tenaga kerja khsusunya para pekerja konstruski di Provinsi Gorontalo yang khususnya berkaiatn

14 Nur Rofiah. 2016. Implementasi Perlindungan Keselamatan Dan Kesehatan Kerja Bagi Pekerja Proyek Konstruksi Di CV. Mupakat Jaya Teknik (Tinjauan Undang-Undang No.13 Tahun 2003 dan Mashlahah Mursalah). Jurisdictie: Jurnal Hukum dan Syariah. 7 (1): 76 dengan keselamatan dan kesehatan kerja (K3).

Setiap pekerja pada dasarnya mempunyai hak untuk mendapatkan perlindungan atas kesehatan dan keselamatan kerja (K3).16 Lebih lanjut dikatakan bahwa untuk melindungi keselamatan pekerja/buruh guna mewujudkan produktivitas kerja yang optimal, diselenggarakan upaya keselamatan dan kesehatan kerja. Upaya keselamatan dan kesehatan kerja dimaksudkan untuk memberikan jaminan keselamatan dan meningkatkan derajat kesehatan para pekerja/buruh dengan cara pencegahan kecelakaan dan penyakit akibat kerja, pengendalian bahaya di tempat kerja, promosi kesehatan, pengobatan, dan rehabilitasi. ${ }^{17}$

Khusus untuk wilayah Gorontalo sebagaimana hasil wawancara dengan BPJS Ketenagakerjaan Provinsi Gorontalo, menyatakan bahwa perlindungan hukum terhadap pekerja konstruksi dengan difasilitasi melalui sistem penyelengaraan jaminan sosial dilakukan dengan sangat baik oleh BPJS Ketenagakerjaan dan BPJS Kesehatan, ini bisa dilihat dengan jumlah pekerja konstruksi yang didaftarkan mencapai angka 44 ribu orang pekerja dan sekaligus memberikan sinyal bahwa perusahaan jasa konstruksi di Gorontalo telah memenuhi kewajibanya dalam memberikan hak-hak pekerja yang dijaminkan di dalam peraturan perundang undangan terutama terkait dengan komitmen penyelengaraan Kesehatan dan keselamatan kerja (K3) melalui proses pemberian jaminan sosial ketenagakerjaan. Sementara itu, penerapan keselamatan dan Kesehatan Kerja (K3) ini di dasarkan pada UU Ketenagkarjaan, juga bisa dilihat pada Undang-Undang Nomor 1 Tahun

${ }^{15}$ Ibid. hlm. 78

${ }^{16}$ Lihat pasal 86 ayat (1) Undang-Undang No. 13 Tahun 2003 tentang Ketenagakerjaan

${ }^{17}$ Lihat Pasal 86 ayat (2) Undang-Undang No. 13 Tahun 2003 tentang Ketenagakerjaan dan penjelasannya 
1970 Tentang Keselamatan Kerja, dan spesifik bagi Perusahaan Menerapkan Sistem Manajemen K3 itu didasarkan pada Peraturan Menteri Tenaga Kerja Nomor : PER05/MEN/1996 Tentang Sistem Manajemen Keselamatan dan Kesehatan Kerja.

Terkait dengan Tenaga Kerja konstruksi pada Pembangunan Proyekproyek di Gorontalo, hampir sebagian besar perusahaan jasa konstruksi di Provinsi Gorontalo menerapkan komitmen terhadap penerapan K3, hal ini bisa dilihat dari:

1. Adanya komitmen terhadap manajemen yang berkaitan dengan Keselamatan dan Kesehatan Kerja (K3);

2. Penerapan Peraturan Perundangundangan proyek konstruksi Doubledouble Track sebagai implementasi standar Keselamatan dan Kesehatan Kerja (K3) terhadap Peraturan Pemerintah Nomor 50 Tahun 2012;

3. Merujuk kepada standar operasional Ke dalam International Standar Organisation (ISO) 45.000;

4. Penggunaan Alat Pelindung Diri (APD) sesuai standar, yaitu dengan menggunakan helm pengaman, rompi reflector dan sepatu pelindung;

5. Identifikasi terhadap semua risiko dan peluan terkait Keselamatan dan Kesehatan Keja (K3);

6. Pengamanan dalam pekerjaan pengangkatan, pekerjaan electrical, serta pekerjaan di ketinggian;

7. Penanganan keadaan darurat;

8. Metode kerja mencakup cara kerja aman. ${ }^{18}$

Tidak hanya itu, Alat Pelindung Diri (APD) yang biasanya digunakan oleh tenaga kerja konstruksi dalam bekerja dan penerapan keselamatan dan kesehatan kerja terhadap tenaga kerja konstruksi pada

18 Hasil wawancara dengan Manager Eksekutif Lembaga Pengawas Jasa Konstruksi Provinsi Gorontalo, Bapak Abdullah Mansur, wawancara dilakukan pada 2 pembangunan proyek-proyek konstruksi di wilayah Gorontalo selama ini sesuai dengan standar K3, misalnya saja terkait dengan APD, yaitu:

1. Kacamata Pengaman, Kacamata pengaman digunakan untuk melindungi mata dari debu kayu, batu, serpihan besi yang berterbangan ditiup angin. Tidak semua jenis pekerjaan membutuhkan kacamata kerja.Namun pekerjaan yang mutlak membutuhkan perlindungan mata adalah mengelas.

2. Sarung tangan, tujuan utama penggunaan sarung tangan adalah melindungi tangan dari benda-benda keras dan tajam selama menjalankan pekerjaan. Jenis kegiatan yang memerlukan sarung tangan adalah pekerjaan pembesian, pekerjaan kayu. dan pekerjaan-pekerjaan yang memiliki resiko sehingga diperlukan penggunaan sarung tangan.

3. Sepatu pengaman, Sepatu kerja (safety shoes) merupakan perlindungan terhadap kaki. Setiap pekerja konstruksi perlu memakai sepatu denga sol tebal supaya bisa bebas berjalan dimana-mana tanpa terluka oleh bendabenda tajam atau alat berat. Bagian muka sepatu harus cukup keras (atau dilapisi dengan pelat besi) supaya kaki tidak terluka kalau tertimpa benda dari atas.

4. Helm, (helmet) sangat penting digunakan sebagai pelindung kepala. Helm digunakan untuk melindungi kepala dari bahaya yang berasal dari atas, misalnya barang, baik peralatan atau material konstruksi yang jatuh dari atas.

5. Pelindung telinga, Alat ini digunakan untuk melindungi telinga dari bunyibunyi yang dikeluarkan oleh

Juni 2020 melalui video call aplikasi whatsaap (WA), yang kemudian di tindaklanjuti dengan pengisian daftar wawancara oleh narasumber. 
mesin yang memiliki volume suara yang cukup keras dan bising.

6. Masker, Pelindung bagi pernapasan sangat diperlukan untuk pekerjaan konstruksi. Oleh karena itu diperlukan masker. Misalnya serbuk kayu dan besi sisa dari kegiatan memotong, mengamplas, dan debu-debu bahan bangunan.

7. Sabuk pengaman (safety belt) berfungsi untuk pelaksanaan pekerjaan pada bagian bangunan yang tinggi dan pada pekerjaan beresiko tinggi dengan tidak ditemukannya pijakan kaki.

8. Pakaian kerja, Pakaian kerja bertujuan pemakaian pakaian kerja ialah melindungi badan manusia terhadap pengaruh-pengaruh yang kurang sehat atau yang biasa melukai badan.

9. P3K, Apabila terjadi kecelakaan kerja baik yang bersifat ringan ataupun berat pada pekerjaan konstruksi, sudah seharusnya dilakukan pertolongan pertama pada kecelakaan di proyek. Adapun jenis dan jumlah obat-obatan disesuaikan dengan aturan yang berlaku. Selain peralatan standar di atas, perusahaan konstruksi sebaiknya menyediakan tanda-tanda (mark) dalam proyek. Tanda dalam proyek konstruksi memberikan informasi berupa tanda-tanda pada area yang mengandung resiko tinggi kecelakaan.Tanda ini merupakan kewajiban bagi pengelolah proyek.

10. Adanya Pembinaan terhadap Sumber Daya Manusia terkait dengan Keselamatan dan Kesehatan Kerja (K3).

11. Peningkatan terhadap pemahaman standar Keselamatan dan Kesehatan Kerja (K3).

19 Hasil wawancara dengan Ketua BIdang Jasa Konstruksi Dinas Pekerjaan Umum dan perumahan Rakyat Provinsi Gorontalo, Fri Sumiyati Bilakonga, wawancara dilakukan pada 3 Juni 2020 melalui video
12. Adanya pemenuhan fasilitas serta peralatan yang berkaitan dengan Keselamatan dan Kesehatan Kerja (K3).

13. Pengawasan yang dilakukan oleh personil yang berkompeten dalam bidang Keselamatan dan Kesehatan Kerja (K3). ${ }^{19}$

Terkait dengan tenaga kerja konstruksi di Provinsi Gorontalo, hampir sebagian besar yang bekerja di perusahaan konstruksi besar, dipersyaratkan harus memiliki sertifikasi yang diterbitkan oleh Kementerian Ketenegakerjaan, cara memperoleh sertifikat pelatihan kerja yang dilaksanakan hampir setiap tahun oleh Kementerian Ketenagakerjaan, yang difasilitasi oleh Dinas Ketenagakerjaan Provinsi Gorontalo. Kementerian ketenagakerjaan perwakilan Provinsi Gorontalo, juga sering melaksanakan berbagai macam bimbingan teknis dan pelatihan khusus terkait dengan Pembinaan terhadap Sumber Daya Manusia khususnya terkait dengan Keselamatan dan Kesehatan Kerja dan juga Peningkatan terhadap pemahaman standar Keselamatan dan Kesehatan Kerja (K3).

Berbagai tanggapan yang diberikan oleh pekerja konstruksi di Gorontalo yang salah satunya menyatakan bahwa selama mereka bekerja diperusahaan konstruksi (istilah yang mereka gunakan adalah perusahaan kontraktor) aspek penting yang selalu diperhatikan dan diperingatkan oleh perusahaan melalui mandor (pengawas) adalah keselamatan harus diutamakan. Hampir sebagian besar yang merupakan pekerja kontrak diberikan fasilitas alat pelindung diri (APD), seperti helm proyek, baju proyek dan sejumlah alat penunjang keselamatan kerja yang lain dari perusahaan namun terkadang terdapat pekerja konstruksi

call aplikasi whatsaap (WA), yang kemudian di tindaklanjuti dengan pengisian daftar wawancara oleh narasumber. 
yang sedang bekerja tidak menggunakan beberapa alat pelindung diri yang telah diberikan oleh perusaahan. ${ }^{20}$ Merujuk pada hal tersebut, maka kesehatan dan keselamatan kerja juga tergantung sikap dan tindakan yang dilakukan oleh masing-masing orang, dalam hal ini adalah pekerja konstruksi.

Selama ini sebelum pekerja konstruksi mulai bekerja, pihak perusahaan kontraktor terlebih dulu meminta KTP dan KK serta beberapa persyaratan lain, dimana menurut pihak perusahaan, data-data yang diminta tersebut, selain untuk kepetingan administrasi perusahaan, juga akan dijadikan sebagai prosedur administrasi ke pihak BPJS untuk mendapatkan layanan asurasi kesehatan dan kecelakaan kerja. ${ }^{21}$

Merujuk pada fakta-fakta di atas, jika dihubungkan dengan konsep perlindungan hukum sebagaimana yang diamanatkan di dalam pasal Pasal 86 dan pasal 87 UU Ketenagakerjaan yang mensyaratkan adanya suasana yang aman dan tentram bagi karyawan dalam bekerja di sebuah perusahaan, dimana perusahaan tersebut wajib untuk menghindari adanya faktorfaktor yang dapat menyebabkan timbulnya pengaruh terhadap Kesehatan dan sekaligus juga dapat mengancam keselamatan kerja bagi para karyawannya terutama pada pekerja konstruksi dalam menjalankan pekerjaanya, diantaranya melalui analisis kemungkinan-kemungkinan yang dapat mempengaruhi selama proses pekerjaan berlangsung seperti; faktor manusia, faktor peralatan, faktor sumber bahaya, dan faktor lain yang dihadapi.

Persoalan pemenuhan hak kepada para pekerja konstruksi sebagai pemenuhan terhadap perlindungan Kesehatan dan Keselamatan Kerja (K3), misalnya untuk mendapatkan jaminan asurasi kesehatan dan

20 Bapak Taufik Ismail merupakan warga Kabupten Gorontalo yang diwawancara melalui aplikasi WA secara langsung. Wawancara dilakukan pada 3 Juni 2020. kecelakaan kerja di wilayah Provinsi Gorontalo sampai dengan saat ini telah berjalan dengan baik, sebab hampir sebagian besar perusahaan konstruksi telah memenuhi kewajiabnya untuk memberikan jaminan asuransi kepada para pekerjanya. Selain itu, implementasi K3 dalam aspek pemenuhan standar keselamatan kerja melalui alat pelindung diri (APD) pada umumnya telah disediakan oleh pihak perusahaan kepada para pekerjanya. Hal lain yang turut berpengaruh adalah terkait pemenuhan sumber daya manusia melalui peningkatan skill telah dilakukan melalui sejumlah pelatihan-pelatihan yang dilaksanakan oleh Dinas Ketenagkerjaan yang bekerjasama dengan Kementerian Ketenagakerjaan.

\section{Faktor Penghambat Perlindungan Hukum Jaminan Kesehatan dan Keselamatan Kerja (K3) Terhadap Tenaga Kerja Konstruksi di Provinsi Gorontalo}

Sejak Indonesia merdeka pemerintah telah mewujudkan berbagai instrumen hukum terkait permasalahan ketenagakerjaan termasuk di dalam UUD 1945, yang cakupan materinya nyaris meliputi segala aspek permasalahan ketenagakerjaan. Perlu diketahui, Bahwa Isu ketenagakerjaan merupakan salah satu permasalahan yang menjadi bagian pembahasan dalam amandemen UUD 1945. Hadirnya isu ketenagakerjaan dalam proses pembahasan amandemen UUD 1945 memperlihatkan komitmen negara untuk melindungi hak setiap komponen yang ada termasuk hak warga negara untuk memperoleh pekerjaan dan bekerja sesuai dengan harkat martabat kemanusiaannya. Hal ini sebagaimana tertuang dalam Pasal 28D ayat (2) UUD 1945 yang menegaskan bahwa setiap orang berhak untuk bekerja serta mendapat imbalan dan perlakuan yang adil dan layak dalam

\footnotetext{
${ }^{21}$ Bapak Djefriyanto Katili merupakan warga Kabupten Gorontalo yang diwawancara melalui aplikasi WA secara langsung. Wawancara dilakukan pada 3 Juni 2020.
} 
hubungan kerja. Konstruksi pasal tersebut adalah negara memberikan jaminan bagi setiap warganya untuk mendapatkan pekerjaan dan memperoleh hak atas pekerjaan yang dilakukannya. ${ }^{22}$

Hak-hak yang didapati orang secara rasional dianggap abadi dan tetap berlaku. ${ }^{23}$ Tiap-tiap orang lain, termasuk pemerintah harus mengindahkannya, dengan membuat hukum atas dasar hak-hak alamiah tersebut. ${ }^{24}$ Tercatat beberapa undang-undang yang khusus memuat permasalahan hak, kewajiban dan kedudukan para pihak terkait dalam ketenagakerjaan, misalnya UU. No. 23 Tahun 1948 tentang Pengawasan Perburuhan, UU No. 21 Tahun 1954 tentang Perjanjian Perburuhan dan UU No. 22 Tahun 1957 tentang Penyelesaian Sengketa Perburuhan. ${ }^{25}$ serta beberapa peraturan perundang undangan terkait lainya.

Peran pemerintah akan semakin terlihat ketika pola hubungan pekerjapengusaha berubah menjadi hubungan industrial $^{26}$ yang tidak saja melibatkan pekerja dan pengusaha akan tetapi menegaskan posisi pemerintah sebagai pihak ketiga. Sebab sebagai penganut "Negara kesejahteraan" (welfare state) maka tidak ada alasan bagi Negara/Pemerintah untuk tidak memasuki segala lini kehidupan warga negaranya, dengan tujuan utamanya adalah mewujudkan kesejahteraan bagi segenap rakyat Indonesia, mental dan spiritual, atau dengan istilah untuk sebesar-besarnya kemakmuran rakyat Indonesia.

Hampir tidak ada program kerja dalam berbagai lintasan kebijakan yang diambil dan dikeluarkan untuk menunjang tujuan negara

22 Weny A. Dungga dan Abdul Hamid Tome. 2019. Identifikasi Faktor Penghambat Penyelenggaraan Pengawasan Ketenagakerjaan Di Provinsi Gorontalo. Jurnal Jambura law Review, 1 (1): 67.

${ }^{23}$ Dolot Alhasni Bakung dan Mohamad Hidayat Muhtar. 2020. Determinasi Perlindungan Hukum Pemegang Hak Atas Neighboring Right. Jurnal Jambura law Review. 2 (1): 1

24 Maria Alfons. 2017. "Implementasi Hak Kekayaan Intelektual Dalam Perspektif Negara Hukum". Jurnal legislalasi Indonesia, 14 (3: 2 (walfare state) dari pusat bahkan sampai di daerah pasti mengalami yang namanya hambatan dan kendala. Hambatan dan kendala yang hadapi sebagai imbas suatu program kerja dan kebijakan merupakan saran untuk selalu melakukan evaluasi dan perbaikan kinerja. Demikian juga terkait dengan program kerja melalui sejumlah kebijkan yang legal formalkan ke dalam sejumlah peraturan perundang undangan yang ditujukan untuk Perlindungan Hukum bagi pemenuhan Jaminan Kesehatan dan Keselamatan Kerja (K3) Terhadap Tenaga Kerja Konstruksi di Provinsi Gorontalo.

Perlu diketahu, bahwa berdasarkan hasil wawancara dengan manager eksekutif Lembaga Pengawas Jasa Konstruksi Provinsi Gorontalo, Dinas Pekerjaan Umum dan Perumahan Rakyat (PUPR) Provinsi Gorontalo, dalam hal ini adalah ketua Bidang Jasa Konstruksi dan beberapa narasumber lain, ada beberapa hal yang diidetifikasi dan ditemukan oleh peneliti mengenai hambatan Perlindungan Hukum bagi pemenuhan Jaminan Kesehatan dan Keselamatan Kerja (K3) Terhadap Tenaga Kerja Konstruksi di Provinsi Gorontalo. Adapun hasil indentifikasi mengenai hambatan yang dimaksud adalah sebagai berikut:

\section{Lemahnya Pengawasan Ketenagakerjaan}

Peraturan kesehatan dan keselamatan kerja memang sudah memiliki undangundang yang sah dimata hukum. Namun, pemerintah sendiri masih kurang dalam hal mengawasi berjalannya peraturan hukum tersebut. Pemerintah hanya

25 Ashabul Kahf. 2016. Perlindungan Hukum Terhadap Tenaga Kerja. Jurnal Jurisprudentie. 3 (2): 61-62

26 Hubungan Industrial merupakan istilah pengganti dari Hubungan Perburuhan yang merupakan terjemahan dari Labour relation, mengingat kompleksitas permasalahan perburuhan yang melampaui hubungan buruh-majikan, maka melalui LKS Tripartit Nasional No. 9 Tahun 1985 istilah Hubungan Perburuhan diganti menjadi Hubungan Industrial. Lih. Eko Wahyudi, dkk. Hukum Ketenagakerjaan, (Jakarta; Sinar Grafika, 2016) 
menganggap semuanya akan berjalan lancer bila sudah memiliki hukum yang kuat. Padahal dalam kenyataannya, penerapan K3 masih sangat kurang meskipun telah memiliki Undang-Undang yang kuat. Itulah penyebab masih adanya perusahaan yang belum bisa melaksanakan program kesehatan dan keselamatan kerja dengan baik dan benar, misalnya terkait dengan kepatuhan perusahaan dalam memenuhi kewajiban untuk mengikutseratkan pekerjanya untuk mendapatkan jaminan sosial ketenagakerjaan. ${ }^{27}$

\section{Faktor Sumber Daya Manusia}

Saat ini jumlah pengawas ketenagakerjaan yang dimiliki oleh pemerintah Provinsi Gorontalo berjumlah 15 orang, yang terdiri dari 11 orang pengawas umum, 2 orang pengawas spesialis, dan 2 orang PPNS Ketenagakerjaan. Sedangkan perusahaan yang diawasi berjumlah 2454 perusahaan dan \pm 33.549 tenaga kerja yang tersebar diseluruh wilayah Provinsi Gorontalo. Data diatas, memperlihatkan bahwa jumlah pengawas ketenagakerjaan Provinsi Gorontalo tidak berbanding lurus dengan jumlah perusahaan dan tenaga kerja yang diawasi. Artinya bahwa pemerintah Provinsi Gorontalo mengalami kekurangan pengawas ketenagakerjaan. Jika merujuk pada Pasal 8 ayat (1) Permanaker No. 33 Tahun 2016 yang mengharuskan pengawas ketenagakerjaan wajib menyusun dan melaksanakan rencana kerja pemeriksaan paling sedikit 5 (lima) perusahaan setiap bulan, maka dalam 1 (satu) tahun pengawas ketenagakerjaan wajib melakukan pemeriksanaan 60 perusahaan. Apabila dilakukan perbandingan antara jumlah pengawas

27 Khikmatul Heny Masitoh, et, al. 2017. Pelaksanaan Perlindungan Hukum bagi Awak Kapal Pada PT Palayaran Nasional Indonesia (Pelni) Semarang. Jurnal Diponegoro Law Review, 6 (2): 8 ketenagakerjaan yang dimiliki pemerintah Provinsi Gorontalo saat ini, 15 orang pengawas ketenagakerjaan, dengan jumlah perusahaan yang ada, 2.454 perusahaan, maka dapat dihasilkan angka pembandingnya sebesar 1 orang : 164 perusahaan. Jumlah tersebut sudah termasuk pengawas spesialis dan PPNS ketenagakerjaan. Apabila hanya dilakukan penghitungan perbandingan murni pengawas ketenagakerjaan yang berjumlah 11 orang, maka hasilnya adalah 1 orang: 233 perusahaan. Jumlah ini sangat besar, jauh dari apa yang tercantum dalam regulasi yang ada. ${ }^{28}$

\section{Faktor Anggaran}

Alokasi anggaran pengawasan ketenagakerjaan di Provinsi Gorontalo bersumber dari APBN dan APBD. Berikut adalah alokasi anggaran pengawasan ketenagakerjaan di Provinsi Gorontalo.

Tabel. 1.

Alokasi Anggaran Pengawasan Ketenagakerjaan Provinsi Gorontalo

\begin{tabular}{cccc}
\hline No & $\begin{array}{c}\text { Sumber } \\
\text { Anggaran }\end{array}$ & Tahun & Jumlah \\
\hline 1 & $\begin{array}{c}\text { APBN } \\
\text { Pusat }\end{array}$ & 2015 & $\begin{array}{c}\text { Rp. } \\
592.615 .000\end{array}$ \\
\hline & & 2016 & $\begin{array}{c}\text { Rp. } \\
770.400 .000\end{array}$ \\
\hline & & 2017 & Rp. \\
& & & 829.050 .000 \\
\hline & & 2018 & Rp. \\
& & & 556.666 .000 \\
\hline & & & Rp. \\
& & & 200.000 .000 \\
& APBD & 2015 & \\
\hline & Provinsi \\
Gorontalo & & & Rp. \\
& & & 200.000 .000 \\
\hline & & 2017 & Rp. \\
& & & 132.000 .000 \\
\hline & & 2018 & Rp. \\
& & & 97.150 .000 \\
\hline
\end{tabular}

Sumber: Dinas Penanaman Modal, ESDM, \& Transmigrasi, 2018.

28 Weny A. Dungga dan Abdul Hamid Tome. Op..Cit.., Hlm. 9-10 
Berdasarkan tabel di atas, menunjukan bahwa penyelenggaraan pengawasan ketenagakerjaan di Provinsi Gorontalo paling banyak bersumber dari APBN, sejak tahun 2015-2017 alokasi anggaran yang bersumber dari APBN mengalami kenaikan tetapi pada tahun 2018 alokasi anggaran tersebut mengalami penurunan, sedangkan alokasi anggaran yang bersumber dari APBD Provinsi Gorontalo sejak tahun 2015-2018 mengalami penurunan.

Apabila dilihat dari diundangkannya UU No. 23 Tahun 2014 tentang Pemerintahan Daerah, yang menjadikan sub bidang pengawasan ketenagakerjaan menjadi kewenangan provinsi, maka seharusnya pemerintah daerah perlu melakukan langkah antisipatif terkait pola penganggaran dalam mendukung optimalisasi penyelenggaraan pengawasan ketenagakerjaan di daerah.

\section{Faktor Kesadaran Pekerja}

Berdasarkan hasil wawancara dengan manager eksekutif Lembaga Pengawas Jasa Konstruksi Provinsi Gorontalo, bahwa Berdasarkan informasi yang diperoleh dari pekerja dan juga temuan di lapangan bahwa pihak perusahaan telah menyiapkan sejumlah alat pelindung diri (APD) kepada para pekerja khsusunya pekerja Konstruksi, namun banyak ditemukan bahwa ternyata pekerja konstruksi tersebut tidak menggunakan alat pelindung diri yang diberikan oleh pihak perusahaan dalam melaksakan pekerjaanya. Sehingga hal ini juga menjadi masalah dalam melakukan pemenuhan konsep Kesehatan dan Keselamatn Kerja (K3), dimana pihak perusahaan telah memenuhi kewajibanya untuk menyediakan APD, namun disisi lain, pekerja yang kurang memperhatikan mengenai pemenuhan standar keselamatan kerja tersebut. Selain itu juga peran mandor di dalam melakukan pengawasan terhadap para pekerja yang bekerja di sejumlah proyek konstruski nayatanya juga kurang maksimal dalam menjalankan tugasnya, hal inilah yang menurut penulis juga pelu untuk di perhatikan mengenai kesadaran pada mandor dalam menjalankan tugas untuk mengecek dengan teliti para pekerja sebelum mereka melakukan pekerjaan dipastikan terlebih dahulu untuk memenuhi alat pelindung diri (APD).

\section{Kurangnya Kesadaran Pimpinan Perusahaan}

Faktor kurangya kesadaran dari pimpinan perusahaan jasa konstruksi untuk mendaftarkan pekerjanya ke dalam program Jaminan Sosial Tenaga Kerja, kuranya kesadaran yang dimaksud adalah pimpinan perusahaan dengan sukarela datang untuk mendaftarkan pekerja tanpa terlebih dahulu diingatkan oleh pihak BPJS Ketenakeerjaan dan Kesehatan, walaupun pada akhirnya pihak perusahaan mendaftarkan pekerjanya ke BPJS, akan tetapi hal tersebut hanya sebagai konsekuensi setelah pihak BPJS melanyangkan surat peringatan kepada pihak perusahaan untuk segera mendaftarkan pekerjanya. Berdasarkan data dari Layanan Pengadaan Secara Elektronik (LPSE) Kota Gorontalo tahun 2020 jumlah proyek yang dilelang sebanyak 148 proyek, tetapi yang terdaftar di BPJS Ketenagakerjaan baru 6 Proyek, yaitu:

Tabel 2

Jumlah Perusahaan Kontraktor yang terdaftar di BPJS

\begin{tabular}{lll}
\hline No & \multicolumn{1}{c}{ Nama Proyek } & $\begin{array}{l}\text { Nama } \\
\text { Perusahaan }\end{array}$ \\
\hline 1 & $\begin{array}{l}\text { Pembuatan Jalan } \\
\text { Setapak Kelurahan } \\
\text { Tanjung Kramat }\end{array}$ & $\begin{array}{l}\text { Sultan } \\
\text { Persada }\end{array}$ \\
\hline 2 & $\begin{array}{l}\text { Pembuatan Jalan } \\
\text { Setapak Kelurahan } \\
\text { Tenilo }\end{array}$ & Bintang \\
& Konstruksi \\
\hline
\end{tabular}




\begin{tabular}{|c|c|c|}
\hline 3 & $\begin{array}{l}\text { Penataan Halaman } \\
\text { Rudis Walikota }\end{array}$ & $\begin{array}{l}\text { Cempaka Mas } \\
\text { CV }\end{array}$ \\
\hline 4 & $\begin{array}{l}\text { Pembuatan Jamban } \\
\text { Keluarga Kelurahan } \\
\text { Pilolodaa }\end{array}$ & \\
\hline 5 & $\begin{array}{lr}\text { Pembuatan } & \text { Jalan } \\
\text { Setapak } & \text { di } \\
\text { Kelurahan } & \\
\text { Molosipat U } & \\
\end{array}$ & Rifki Dwi Putra \\
\hline 6 & $\begin{array}{l}\text { Pembangunan } \\
\text { Kantor DPRD Kota } \\
\text { Gorontalo }\end{array}$ & $\begin{array}{l}\text { PT Takabeya } \\
\text { Teknik } \\
\text { Konstruksi }\end{array}$ \\
\hline
\end{tabular}

Sumber: BPJS Ketenagakerjaan Provinsi Gorontalo Merujuk pada hal di atas, maka apabila pihak BPJS tidak memberikan peringatan, bisa saja pihak perusahaan tidak akan mau mendaftarkan pekerjanya ke dalam program Jaminan Sosial Tenaga Kerja, dan hal ini tentu menjadi penghambat perlindungan hukum jaminan K3 bagi para pekerja konstruksi. Faktor kesadaran inilah yang masih membutuhkan perhatian agar terus digaungkan kepada para pekerja khsusunya kepada pimpinan perusahaan jasa Konstruksi untuk benar-benar memperhatikan mengenai hak-hak pekerjanya dalam mendapatkan jaminan dan akses asurasi kesehatan dan kecelakaan kerja selama mereka bekerja di perusahaan tersebut.

Tantangan dan hambatan tidak bisa lepas dari sebuah sistem yang dijalankan, maka hal ini harusnya dievaluasi sebagai proses memperbaiki sistem pengelolaan dari sebuah kebijakan yang dijalankan dalam hal sistem penegakan hukum terhadap jaminan kesehatan dan keselamatan kerja bagi pera pekerja konstruksi khususnya yang ada di Provinsi Gorontalo.

\section{PENUTUP}

\section{Kesimpulan}

Mengacu kepada pembahasan sebagaimana yang telah diuraikan, makadapat disimpulkan bahwa; Pertama, perlindungan hukum jaminan Kesehatan dan Keselamatan
Kerja (K3) Terhadap Tenaga Kerja Konstruksi di Provinsi Gorontalo, sampai dengan saat ini telah berjalan dengan baik, sebab hampir sebagian besar perusahaan konstruksi telah memenuhi kewajiabnya untuk memberikan jaminan asuransi kepada para pekerjanya. Kemudian terkait dengan implementasi K3 dalam aspek pemenuhan standar keselamatan kerja melalui alat pelindung diri (APD) semuanya disediakan oleh pihak perusahaan kepada para pekerjanya, maka dapat dikatakan jaminan perlindungan hukum terkait dengan kesehatan dan keselamatan kerja (K3) berjalan dengan baik di provinsi Gorontalo, namun belum maksimal dikarenakan faktor kesadaran dari pekerja itu sendiri. Kedua, faktor penghambat perlindungan hukum jaminan Kesehatan dan Keselamatan Kerja (K3) terhadap tenaga kerja konstruksi di Provinsi Gorontalo, dapat diidetifikasi dan terdiri atas: Lemahnya Pengawasan Ketenagkerjaan; Faktor Sumber Daya Manusia; Faktor Anggaran; Faktor Kesadaran Pekerja; dan Kurangya Kesadaran Pimpinan Perusahaan untuk mendaftarakan Pekerja ke dalam program Jaminan Sosial Tenaga Kerja.

\section{Saran}

Adapun saran atau rekomendasi atas permasalahan yang didapati antara lain: pertama, Pemerintah Provinsi melalui Lembaga Pengawas Ketenakerjaan sebaiknya menambah jumlah pengawas tenaga kerja, mengingat antara jumlah pengawas dengan jumlah yang diawasi sangat tidak proporsional; kedua, menambah jumlah anggaran operasional kepada lembaga pengawas ketenagakerjaan di Provinsi Gorontalo, sebab tingkat mobilisasi pangawas ketenagakerjaan pasti sangat padat dan membutuhkan anggaran yang cukup untuk menunjang kinerjanya yang besar tersebut; ketiga, Pemerintah Provinsi Gorontalo, yang dalam hal ini bisa melalui Dinas Pekerjaan Umum dan Perumahaan Rakyat bersama dengan Dinas Ketenagakerjaan sebaiknya 
mengadakan sosialisasi kepada perusahaanperusahaan jasa konstruski terkait dengan kesadaran untuk melindungi para pekerjanyan untuk mendaftarkan pekerjanya ke dalam program Jaminan Sosial Tenaga Kerja; keempat, lebih memperkuat lagi sistem pengawasan terhadap pengunaan alat pelindung diri bagi para pekerja yang ada di perusahaan-perusahaan konstruksi yang ada di provinisi Gorontalo, hal ini untuk memimalisir angka kecelakaan akibat penggunaan APD yang tidak sesuai standar keselamatan.

\section{REFERENSI}

\section{Buku}

BPS. (2019). Direktori Perusahaan Konstruksi Provinsi Gorontalo 2019. Gorontalo: Badan Pusat Statistik.

Joni, B. R. (2013). Hukum Ketenagakerjaan . Bandung: Pustaka Setia.

PUPR, D. B. (2018). Kemeriahan Konstruksi Indonesia 2018. Jakarta : Konstruksi.

Sudarjadi. (2010). Kompilasi Hukum Ketenagakerjaan Jamsostek. Yogyakarta: Pustaka Yustisia.

Wahyudi, E. (2016). Hukum Ketenagakerjaan. Jakarta: Sinar Grafika.

\section{Artikel Jurnal}

Achir, N. (2020). Anotasi Normatif Terhadap Peraturan Daerah Tentang Transparansi. Jurnal Jambura Law Review, 2 (1), 85.

Akbar, F. (2016). Politik Hukum Perlindungan Hakim. Jurnal Cita Hukum, 4 (1), 13.

Alfons, M. (2017). Implementasi Hak Kekayaan Intelektual dalam Perspektif Negara Hukum . Jurnal Legislasi Indoesia, 14 (3), 2.

Bakung, D. A. (2020). Determinasi Perlindungan Hukum Pemegang Hak Atas Neighboring Right. Jurnal Jambura Law Review, 2 (1), 1.

Charda S, U. (2010). Perlindungan Hukum Ketenagakerjaan Terhadap Tenaga
Kerja Anak yang Bekerja di Luar Hubungan Kerja pada Bentuk Pekerjaan Terburuk. Jurnal Ilmu Hukum (Syiah Hukum), 12 (2), 117.

Dungga, W. A. (2019). Identifikasi Faktor Penghambat Penyelenggaraan Pengawasan Ketenagakerjaan Di Provinsi Gorontalo. Jurnal Jambura Law Review, 1 (1), 67.

Kahf, A. (2016). Perlindungan Hukum Terhadap Tenaga Kerja. Jurnal Jurisprudentie, 3 (2), 61-62.

Khoe, F. N. (2013). Hak Pekeerja yang Sudah Bekerja Namun Belum Menandatangani Perjanjian Atas Upah Ditinjau Berdasarkan Undang-Undang Nomor 13 Tahun 2003 Tentang Ketenagakerjaan. Jurnal Ilmiah Mahasiswa Universitas Surabaya, 2 (1), 3.

Masitoh, K. H. (2017). Pelaksanaan Perlindungan Hukum bagi Awak Kapal Pada PT Palayaran Nasional Indonesia (Pelni) Semarang. Jurnal Diponegoro Law Review, 6 (2), 8.

Priyadi, U. (2013). Pendampingan Hukum Hak Pekerja (Usia Produktif) Berdasarkan Hukum Ketenagakerjaan. Jurnal Inovasi dan Kewirausahaan, 2 (2), 101.

Rofiah, N. (2016). Implementasi Perlindungan Keselamatan dan Kesehatan Kerja Bagi Pekerja Proyek Konstruksi di CV. Mupakat Jaya Teknik (Tinjauan Undang-Undang No. 13 Tahun 2003 dan Mashlahah Mursalah). Jurisdictie: Jurnal Hukum dan Syariah, 7 (1), 76.

Suhartoyo. (2019). Perlindungan Hukum Bagi

Buruh Dalam Sistem Hukum

Ketenagakerjaan Nasional.

Adminitrative Law \& Governance Journal, 2 (2), 326-327.

Suyanto, H. d. (2016). Perlindungan Hukum Terhadap Hak-Hak Pekerja Outsourching Berdasarkan Asas Keadilan. Jurnal Yuridis, 3 (2), 4.

Zulkarnain, A. H. (2016). Perlindungan Hukum Terhadap Pekerja Dalam 
Pelaksanaan Hubungan Industrial. Jurnal Padjajaran Ilmu Hukum, 3 (2), 407-408.

Web Resmi

Hargo, B. (2017, Desember 28). Pekerja Jasa Konstruksi Wajib Dilindungi. Retrieved from Hargo: https://hargo.co.id/berita/pekerjajasa-konstruksi-wajib-dilindungi.html Newswire. (2019, Januari 15). Sepanjang 2018 Kemnaker Catat Terjadi 157.313 Kecelakaan Kerja. Retrieved from Bisnis.com https://ekonomi.bisnis.com/read/201 90115/12/878723/sepanjang-2018kemnaker-catat-terjadi-157.313kecelakaan-kerja

\section{Undang-Undang}

Undang-Undang Dasar Negara Republik Indonesia Tahun 1945

Undang-Undang Nomor 1 Tahun 1970

Tentang Keselamatan Kerja

Undang-Undang Nomor 13 Tahun 2003

Tentang Ketenagakerjaan

Undang-Undang Nomor 23 Tahun 2014

Tentang Pemerintahan Daerah

\section{Interview/Wawancara}

Bilakonga, F. S. (2020, Juni 3). Hasil Wawancara dengan Ketua Bidang Jasa Konstruksi Dinas Pekerjaan Umum dan Perumahan Rakyat Provinsi Gorontalo. (C. Riyadi, Interviewer)

Ismail, T. (2020, Juni 3). Hasil Wawancara Bersama Pekerja di Perusahaan. (C. Riyadi, Interviewer)

Katili, D. (2020, Juni 3). Hasil Wawancara Bersama Pekerja Perusahaan Terkait Jaminan Perlindungan Terhadap Kesehatan dan Keselamatan Kerja yang Dilakukan oleh Perusahaan dalam hal Pemberian Asurasi Kesehatan. (C. Riyadi, Interviewer)

Mansur, A. (2020, Juni 2). Hasil wawancara dengan Manager Eksekutif Lembaga Pengawas Jasa Konstruksi Provinsi Gorontalo. (C. Riyadi, Interviewer) 